\title{
Relationships between photosynthetic plant types in the diet of herbivore mammals and in the environment in the lower Paraná river basin, Argentina
}

\author{
Relación entre los tipos fotosintéticos de plantas presentes en la dieta de mamíferos \\ herbívoros y en el ambiente en la baja cuenca del río Paraná, Argentina
}

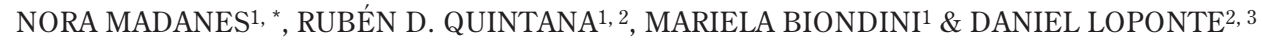 \\ ${ }^{1}$ Grupo de Investigaciones sobre Ecología de Humedales, Laboratorios 56 y 57, Departamento de Ecología, Genética y \\ Evolución. Facultad de Ciencias Exactas y Naturales, Universidad de Buenos Aires, Pabellón II, Ciudad Universitaria, \\ C1428EHA Ciudad de Buenos Aires, República Argentina \\ ${ }^{2}$ Consejo Nacional de Investigaciones Científicas y Técnicas (CONICET) \\ ${ }^{3}$ Instituto Nacional de Antropología y Pensamiento Latinoamericano \\ Corresponding author: noram@ege.fcen.uba.ar
}

\begin{abstract}
In the present study we assess the contribution of $\mathrm{C}_{3}, \mathrm{C}_{4}$ and intermediate $\mathrm{C}_{3}-\mathrm{C}_{4}$ plant species to the diet of both native (Hydrochoerus hydrochaeris, Rhea americana and Logostomus maximus) and introduced (cattle) herbivore species and the abundance of these photosynthetic plant types in different environments of the lower section of the Paraná Basin, Argentina, with similar climate but different hydrological regimes. Data of current plants species and their photosynthetic pathways, both form vegetation and the diet, were compiled from literature. The analysis of annual diets conducted in terms of photosynthetic types showed that the feeding patterns of native as well introduced herbivores varied both spatially and temporally. At each site, the analysis of vegetation and the diet of herbivores in spring indicated that the feeding patterns may depend not only on vegetation availability, but also on the preferences of herbivores and inter-specific interactions under limited resource conditions. These attributes should be taken into account when interpreting the diet of fossil herbivores from isotopic carbon information. Also, the studies on photosynthetic groups enhance our understanding of the relationship between paleodiets and paleoenvironments.
\end{abstract}

Key words: herbivory, Neotropical ecology, photosynthetic plants types.

\section{RESUMEN}

En el presente estudio evaluamos la contribución de especies de plantas $\mathrm{C}_{3}, \mathrm{C}_{4}$ e intermedias $\mathrm{C}_{3}-\mathrm{C}_{4}$, en la dieta de herbívoros nativos (Hydrochoerus hydrochaeris, Rhea americana y Logostomus maximus) y domésticos (reses), y analizamos la abundancia de las plantas presentes que muestran estos tipos fotosintéticos en distintos ambientes, de la sección baja de la Cuenca de Río Paraná, Argentina, con clima similar pero regímenes hidrológicos diferentes. Los datos de la vegetación y de la dieta, así como sus tipos fotosintéticos, fueron obtenidos de datos bibliográficos. El análisis de la dieta anual realizada en términos de tipos fotosintéticos, mostró que los patrones de consumo de los herbívoros silvestres y domésticos variaron espacial y temporalmente. El análisis de la vegetación de cada sitio y la dieta de los herbívoros en primavera indicaron que los patrones de forrajeo no solo dependen de la disponibilidad de la vegetación, sino también de la preferencia de los herbívoros y de las interacciones específicas entre estos bajo condiciones de recursos limitados. Estos atributos deberían ser considerados a la hora de hacer inferencias sobre las dietas y el ambiente de los herbívoros. Los estudios sobre grupos fotosintéticos actuales contribuyen a la interpretación del análisis de isótopos estables del Carbono en la reconstrucción de las relaciones entre paleodietas y paleoambientes.

Palabras clave: ecología neotropical, herbivoría, tipos fotosintéticos de plantas.

\section{INTRODUCTION}

The study of the feeding behavior of herbivores in relation to their diet and to forage availability in the environment is essential for understanding plant-herbivore interactions and ecosystem functioning. There are different methods to characterize dietary patterns in wild animal populations, all with advantages and limitations. Some of these methods include direct and/or indirect observation, microhistological analysis of feces, and determination of stable isotopes such as $\delta^{15} \mathrm{~N}$ and $\delta^{13} \mathrm{C}$ in feces and animal 
tissues (Botha \& Stock 2005). The latter technique has been one of the most important tools for studying plant-animal interactions during the last 20 years.

In particular, $\delta^{13} \mathrm{C}$ values in tissues of modern herbivores serve to reconstruct past environments and diets with implications for archaeological interpretation (DeNiro \& Epstein 1978, Ambrose \& DeNiro 1989, Tieszen \& Boutton 1989, Kock et al. 1995, Fernández et al. 1999, Faranec 2003). The use of $\delta^{13} \mathrm{C}$ in trophic studies relies on the fact that food sources are reflected in the tissues of the consumer (DeNiro \& Epstein 1978, DeNiro 1987, van der Merwe 1989, Schwarcz 1991, Ambrose 1993, Fernández et al. 1999). Thus, $\delta^{13} \mathrm{C}$ values in the tissues of modern and past herbivores indicate the photosynthetic group dominating in the vegetation, since $\mathrm{C}_{3}$ plants have lower values of $\delta^{13} \mathrm{C}$ than $\mathrm{C}_{4}$ plants (Ambrose \& DeNiro 1986, Farquhar et al. 1989, van der Merwe 1989). Furthermore, changes in the isotopic composition of the diet may provide information on environmental and paleoenvironmental characteristics, due to the close relationship between the photosynthetic groups and abiotic factors (van der Merwe 1989, Tieszen 1991). For example, the $C_{4}$ plants are related to warm, dry environments (Smith \& Brown 1973, Theerl \& Stowe 1976, Boutton et al. 1980, Cavagnaro 1988) and to environments with low $\mathrm{CO}_{2}$ concentrations (Monson 1993, Cerling et al. 1997, Ehleringer \& Sage et al. 1999). In this sense, the comparison of the proportion of the different photosyntethic plant types in the diet among herbivores inhabiting different environments, along with the evaluation of their composition in the environment, allow to verify if the differences in the diets (which are indicators of $\delta^{13} \mathrm{C}$ variation in the tissues) are due to differences in the environment. (e.g., Tykot et al. 2009, Yacobaccio et al. 2009)

The lower basin of the Paraná river is adequate for testing this relationship because 1) this area is composed of a high diversity of wetland types with different environmental conditions (Malvárez 1997, Quintana et al. $2005)$; 2) it is inhabited by a variety of wild and domestic herbivore species; 3 ) previous studies (Quintana et al. 1994, 1998a, 1998b, Malvárez 1997, Quintana 2002, 2005, Pereira et al. 2003) reported that the composition of the vegetation in the environment and in the diet of different herbivores differ among sites.

The considerations outlined above lead to the question: Do the proportion of the different photosynthetic plant types in herbivore tissues represent the proportion of these plant types in temperate wetlands? The objective of this study is to analyze feeding patterns and dietary interactions among herbivores in terms of $\mathrm{C}_{3}$, $\mathrm{C}_{4}$ and intermediate $\mathrm{C}_{3}-\mathrm{C}_{4}$ plants present in different environments in order to evaluate whether this variability should be considered when making inferences about past environmental conditions. Our work hypothesis is that the proportion of the functional types in the diet of herbivores is conditioned by feeding patterns at the level of plant species.

\section{METHODS}

\section{Study area}

The lower section of the Paraná Basin shows an important environmental heterogeneity, which defines changes in vegetation composition (Malvárez 1997, Quintana et al. 2005). In this area, the relationship between the feeding patterns of native and introduced herbivore species and the composition of vegetation in different habitats has been previously studied (Quintana et al. 1994, 1998a, 1998b, Quintana 2002, Pereira et al. 2003). In the lower delta of the Paraná River (Fredes stream), Acosta \& Loponte (2002-2004) and Loponte (2008) reconstructed a fraction of the past trophic chains from $\delta^{13} \mathrm{C}$ values in human and animal bone remains.

The study was conducted at four sites located in the lower section of Del Plata Basin (Fig. 1): an island in the lower delta of the Paraná River (LD), Puerto Constanza (PC), Ceibas (CE), and Villaguay (VI). The landscape of LD is characterized by a dense network of channels and dams, and by a mosaic of Salicaceae plantations (Salix L. spp. and Populus L. spp.) usually growing on levees. Natural patches of the bulrush Scirpus giganteus Kunth are present in permanently flooded environments. PC is featured by lowland floodplains dominated by bulrushes Schoenoplectus californicus (C.A. Mey.) Steud. and Panicum grumosum Ness, mid-slopes dominated by Cynodon dactylon (L.) Persoon, Polypogon monspeliensis (L.) Desf. and Luziola peruviana Guelin, and upper slopes covered with open forests of Acacia caven (Mol.) Mol. In CE, the landscape pattern corresponds to plains with a savanna physiognomy of grasses and patches of Prosopis nigra (Gris.) Hieron and Acacia caven (Mol.) Mol. forest; the area is crisscrossed by small lentic streams covered with floating and rooted aquatic plants (Malvárez 1997). In VI, the landscape is a wavy open savanna with patches of gallery forest along the banks of a small stream.

This study involved the analysis of the feeding patterns of the following wild and domestic herbivores: capybaras (Hydrochoerus hydrochaeris Linnaeus), which 
are found in $\mathrm{LD}, \mathrm{PC}$, and $\mathrm{VI}$; greater rheas (Rhea Americana Lynch \& Holmberg) and plains vizcachas (Lagostomus maximus Desmarest), exclusively present in CE; and cattle, reared in PC, CE and VI.

The region has a predominantly temperate climate with rainfall throughout the year. Mean annual temperature is $16{ }^{\circ} \mathrm{C}$ and annual precipitation is 1,000 $\mathrm{mm}$. The studied areas are subject to different hydrological regimes. LD is mainly influenced by the tidal regime of the Río de la Plata River, which causes frequent floods of short duration. PC is affected by the hydrological regime of the Paraná River and, to a lesser extent, by that of the Gualeguaychú River, which causes periodic floodings. VI, on the other hand, is affected by the hydrological regime of the Gualeguay River. In $\mathrm{CE}$, hydrology is dominated principally by rainfall. This site has a climatic-hydrologic pattern characterized by a drougth-waterlogging cycle and it has no influence of river flooding. (Malvárez 1977 , Kandus et al. 2003, Pereira et al. 2003, Quintana et al. 2005).

\section{Data analysis}

Data on the composition and relative abundance of plant species present at each site and in the diet of native and domestic herbivore species were compiled from previous studies carried out in the study area (Quintana et al. 1994, Quintana, 1998a, 1998b, Pereira et al. 2003). In these studies, vegetation data were recorded only for spring due to the difficulty in identifying species during the remaining seasons, while dietary items were studied seasonally over two years. All plant species found in both diet and environment were characterized according to their photosynthetic pathway $\left(\mathrm{C}_{3}, \mathrm{C}_{4}\right.$ and intermediate $\mathrm{C}_{3}-\mathrm{C}_{4}$ plants), based on information gathered from the literature (Black et al. 1969, Black 1971, Smith \& Brown 1973, Waller \& Lewis 1979, Jones 1988). The abundance of each photosynthetic type in the diet of each herbivore species was estimated by season and by environment (Table 1). The seasonal diets of each animal were compared using the Euclidean distance index (Matteucci \& Colma 1982). At each site, the proportions of the photosynthetic types in the diet of capybaras, greater rheas, plains vizcachas and cattle were compared with their respective availability in the environments actually used these herbivores using the Savage's preference index (Manly et al. 1993), and confidence intervals were calculated (Hobbs 1982).

The similarity Czekanowski's index (Matteucci \& Colma 1982) was used to compare quantitatively photosynthetic types a) in the vegetation b) in environments actually used by the studied herbivores, and $\mathrm{c}$ ) in the diet of these herbivores between sites. The dietary items of coexisting herbivores were compared among seasons using the Sorensen's coefficient of similarity based on quantitative data (Matteucci \& Colma 1982).

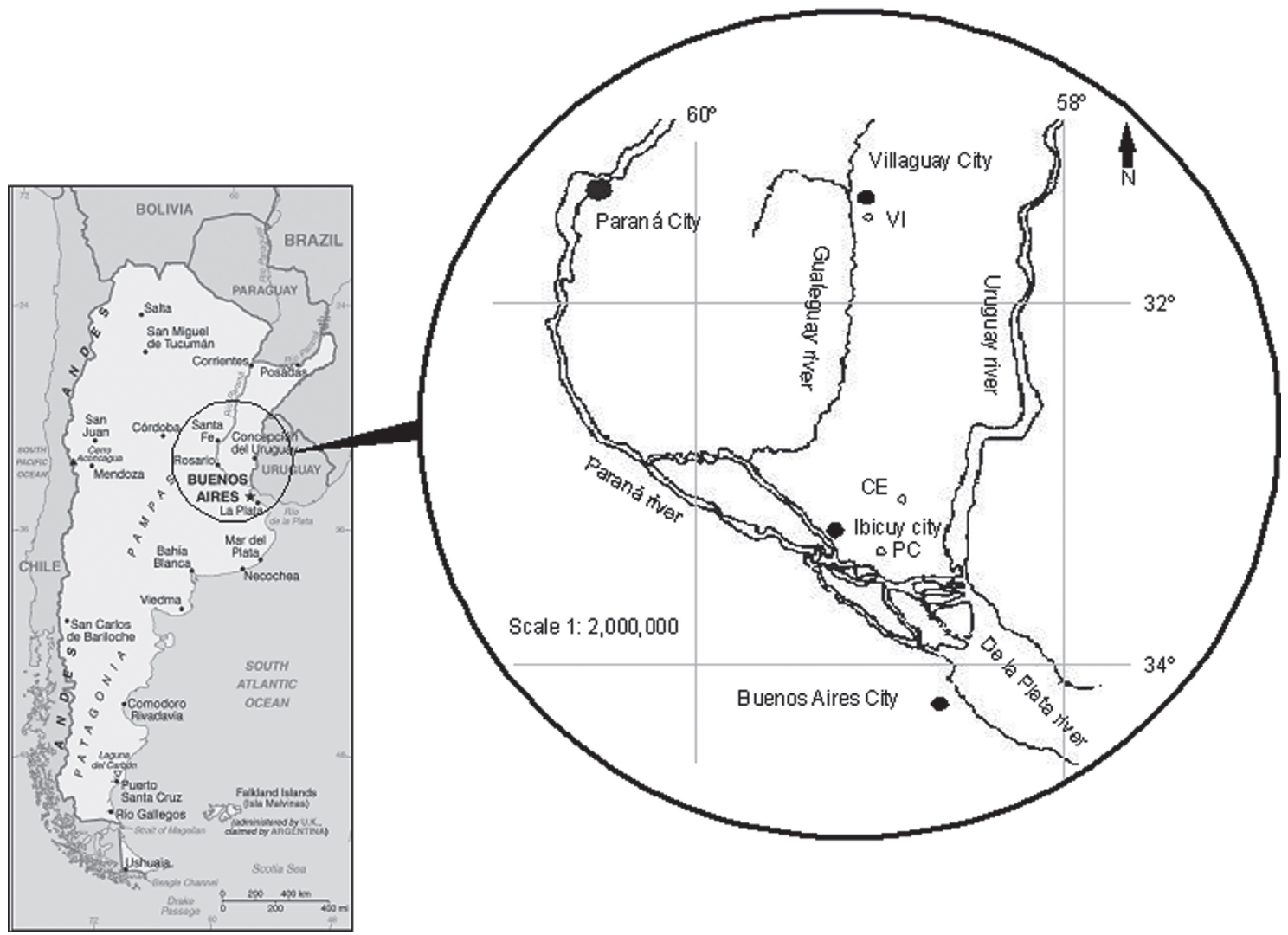

Fig. 1: Location of the studied sites in the lower section of Del Plata Basin. Island in the lower delta of the Paraná River, LD; Puerto Constanza, PC; Ceibas, CE; Villaguay, VI.

Localización de los sitios estudiados en la sección inferior de la Cuenca del Plata. LD: islas del bajo delta del Río Paraná; PC: Puerto Constanza; Ceibas: CE; VI: Villaguay. 


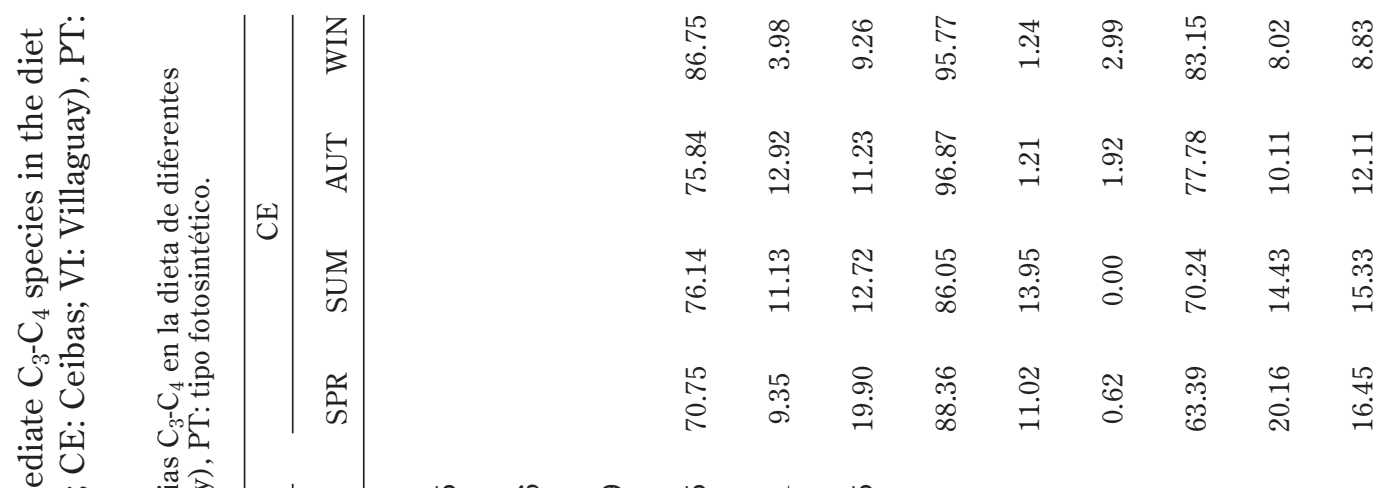

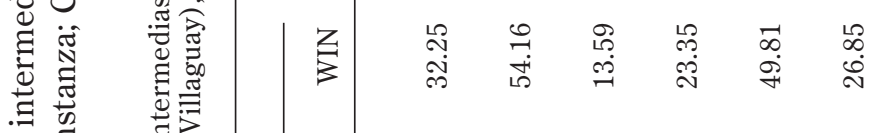

吾范

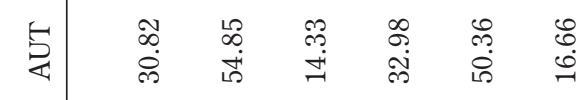

U⿺辶一

లิ

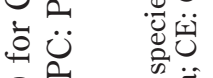

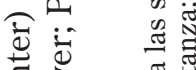

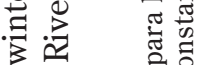

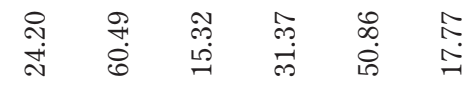

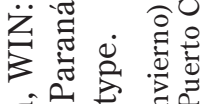

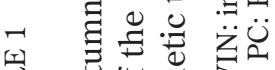

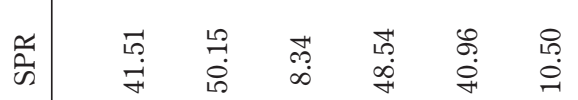

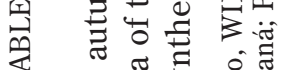

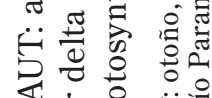

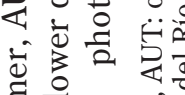

政

क

范芯

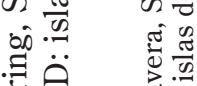

u

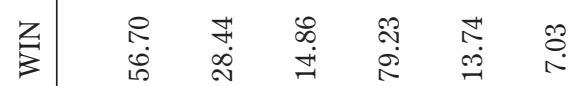

के

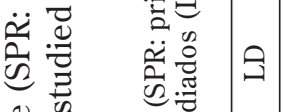

范

증.

吾

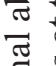

营

क क

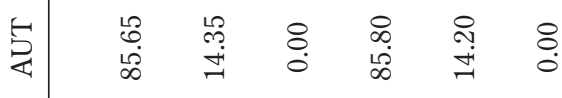

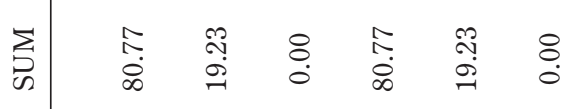

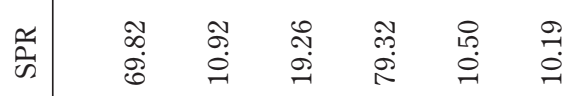

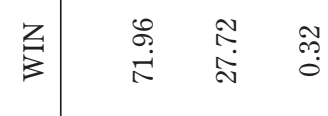

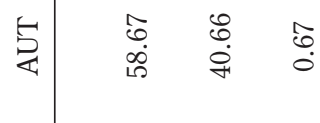

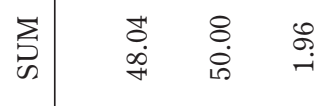

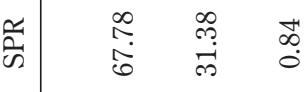

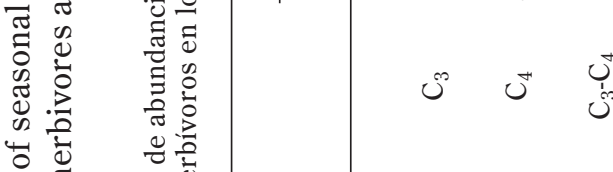

ㄴ.

我若

还

$\frac{\pi}{\tilde{W}}$ 


\section{RESULTS}

The proportion of the three photosynthetic types in the diet of the studied herbivores showed a seasonal variation, their consumption depended on the study site, and coexisting herbivores had different diets (Table 1).

Capybaras consumed photosynthetic types as follows: in $\mathrm{LD}, \mathrm{C}_{3}$ plants in proportion to availability and $\mathrm{C}_{4}$ plants in greater proportion than available; in $\mathrm{PC}, \mathrm{C}_{3}$ and $\mathrm{C}_{4}$ plants in proportion to availability and intermediate $\mathrm{C}_{3}$ $\mathrm{C}_{4}$ plants in greater proportion than available; and in VI, $\mathrm{C}_{3}$ plants in lower proportion than available and $\mathrm{C}_{4}$ plants in greater proportion than available (Table 2). In regard to cattle, in PC the three plant functional types were consumed in proportion to availability, while in VI, $C_{3}$ plants were consumed in proportion to their availability and $\mathrm{C}_{4}$ in greater proportion than available. Plains vizcachas consumed all the plant functional types in greater proportion than available in $\mathrm{CE}$, while in this environment greater rheas consumed $\mathrm{C}_{3}$ and $\mathrm{C}_{4}$ plants in greater proportion than available and $\mathrm{C}_{3}-\mathrm{C}_{4}$ plants in lower proportion than available.

In spring, $\mathrm{C}_{3}$ plants dominated at all sites, with minimum and maximum values in $\mathrm{PC}$ and $\mathrm{LD}$, respectively; $\mathrm{C}_{4}$ plants showed minimum and maximum values in $\mathrm{LD}$ and $\mathrm{PC}$, respectively; and intermediate $\mathrm{C}_{3}-\mathrm{C}_{4}$ plants had lower richness and relative abundance values at all sites (Fig. 2)

The three photosynthetic types showed high similarity when total vegetation was compared among sites (Table 3A), and similarity was even greater among environments actually used by herbivores (Table 3B and 3C). The similarity in the diet of

Mean percentage of $\mathrm{C}_{3}, \mathrm{C}_{4}$ and intermediate $\mathrm{C}_{3}-\mathrm{C}_{4}$ species in the vegetation (Vegetation mean) and in the species diet (Diet mean), preference index (PI) and confidence intervals (CI) of different herbivores at the studied sites (LD: island in the lower delta of the Paraná River; PC:

Puerto Constanza; CE: Ceibas; VI: Villaguay). (a) and (b) indicate photosynthetic types consumed in greater proportion than available and less than available, respectively. In the remaining cases use was proportional to availability.

Porcentaje medio de las especies $\mathrm{C}_{3}, \mathrm{C}_{4}$ e intermedias $\mathrm{C}_{3}-\mathrm{C}_{4}$ en la vegetación (Media de la Vegetación) y en la dieta de los herbívoros (Media de la Dieta), índice de preferencia (PI) y sus correspondientes intervalos de confianza (CI) en los distintos sitios estudiados (LD: islas del bajo delta del Río Paraná; PC: Puerto Constanza; Ceibas: CE; VI: Villaguay). (a) y (b) indica el tipo fotosintético consumido en mayor y menor proporción que lo disponible, respectivamente. En el resto de los casos el consumo fue proporcional a lo disponible.

$\begin{array}{lllll}\text { Photosynthetic type } & \text { Vegetation mean } & \text { Diet mean } & \text { PI } & \text { CI (95\%) }\end{array}$

\begin{tabular}{|c|c|c|c|c|c|}
\hline \multicolumn{6}{|c|}{ Capybara } \\
\hline \multirow[t]{2}{*}{ LD } & $\mathrm{C}_{3}$ & 52.49 & 62.17 & 1.18 & $0.61-1.76$ \\
\hline & $\mathrm{C}_{4}$ & 12.34 & 32.5 & $2.63^{\mathrm{a}}$ & $1.54-3.73$ \\
\hline \multirow[t]{3}{*}{$\mathrm{PC}$} & $\mathrm{C}_{3}$ & 20.89 & 41 & 1.96 & $0.74-3.18$ \\
\hline & $\mathrm{C}_{4}$ & 13.39 & 29.67 & 2.22 & $0.79-3.64$ \\
\hline & $\mathrm{C}_{3}-\mathrm{C}_{4}$ & 2.74 & 17.33 & $6.33^{\mathrm{a}}$ & $3.20-9.45$ \\
\hline \multirow[t]{2}{*}{ VI } & $\mathrm{C}_{3}$ & 18.95 & 33 & $1.74^{\mathrm{a}}$ & $1.12-2.36$ \\
\hline & $\mathrm{C}_{4}$ & 18.89 & 65.83 & $3.48^{\mathrm{a}}$ & $2.70-4.27$ \\
\hline \multicolumn{6}{|c|}{ Plains vizcacha } \\
\hline & $\mathrm{C}_{3}$ & 30.36 & 62.18 & 0.77 & $0.45-1.09$ \\
\hline & $\mathrm{C}_{4}$ & 49.06 & 17.34 & $0.60^{\mathrm{b}}$ & $0.24-0.97$ \\
\hline & $\mathrm{C}_{3}-\mathrm{C}_{4}$ & 20.6 & 20.60 & $0.29^{\mathrm{b}}$ & $0-0.59$ \\
\hline \multicolumn{6}{|c|}{ Greater rhea } \\
\hline \multirow[t]{3}{*}{$\mathrm{CE}$} & $\mathrm{C}_{3}$ & 26.44 & 84.98 & 1.36 & $0.49-2.22$ \\
\hline & $\mathrm{C}_{4}$ & 49.00 & 15.02 & $0.25^{\mathrm{b}}$ & $0-0.60$ \\
\hline & $\mathrm{C}_{3}-\mathrm{C}_{4}$ & 4.35 & 0.00 & $0.09^{\mathrm{b}}$ & $0-0.46$ \\
\hline
\end{tabular}


capybara and cattle among sites was high, but lower than those estimated for the vegetation (Table 3D and 3E).

The diets of coexisting herbivores, in terms of photosynthetic types, showed a high similarity, with values greater than $71 \%$ in all cases (Table 4). In PC, the diets of capybaras and cattle were similar in all seasons except for winter, when the former consumed more $\mathrm{C}_{3}$ and $\mathrm{C}_{3}-\mathrm{C}_{4}$ plants. In $\mathrm{VI}$, the diets of capybaras and cattle were also similar throughout the year, with dominance of $\mathrm{C}_{4}$ plants. In $\mathrm{CE}$, the diets of capybaras, greater rheas and cattle were highly similar, with dominance of $\mathrm{C}_{3}$ plants $\mathrm{C}_{3}$ plants; at this site, the lower similarity was observed between greater rheas and plains vizcachas due to the different contribution of $\mathrm{C}_{4}$ and $\mathrm{C}_{3}-\mathrm{C}_{4}$ plants to their diet.

\section{DISCUSSION}

At present, many studies have showed that feeding patterns of herbivores may depend not only on the vegetation composition and abundance in a particular area, but also on their feeding preference and the inter-specific interaction among them (Quintana 2002, 2003).
In addition, the influence of vegetation on habitat selection, availability of key resources, reproduction, and shelter from predators are also important facts in the plant-animal relationship (Wiens 1992). In agreement with Boutton et al. (1980) and Hoope et al. (2004), this should be taken into account when inferring the relationship between past trophic chains and environmental conditions.

In the present study, the analysis of diet based on the photosynthetic plant types showed that the feeding patterns of wild and domestic herbivores varied both spatially and temporally. These variations may result from spatial and temporal heterogeneity in the environment, as suggested by authors who studied feeding patterns in terms of botanical composition (Quintana et al. 1994, Quintana 1998a, 1998b, Pereira et al. 2003). In addition, it is expected that differences in the proportion of the consumed photosynthetic functional groups would determine variations in the dietary isotopic signatures for the same species at different sites or for different species at the same site. For example, Loponte (2008) reported that $\delta^{13} \mathrm{C}$ values of collagen from fossil Myocastor coypus Molina1782 were $17.96 \%$ for the lower section of the Del Plata Basin, and $-16 \%$ for the Salado River, a

(A)
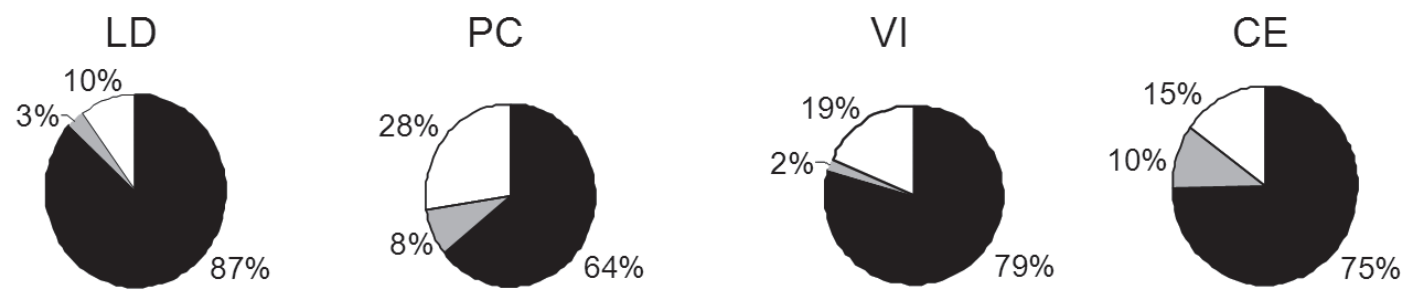

(B)
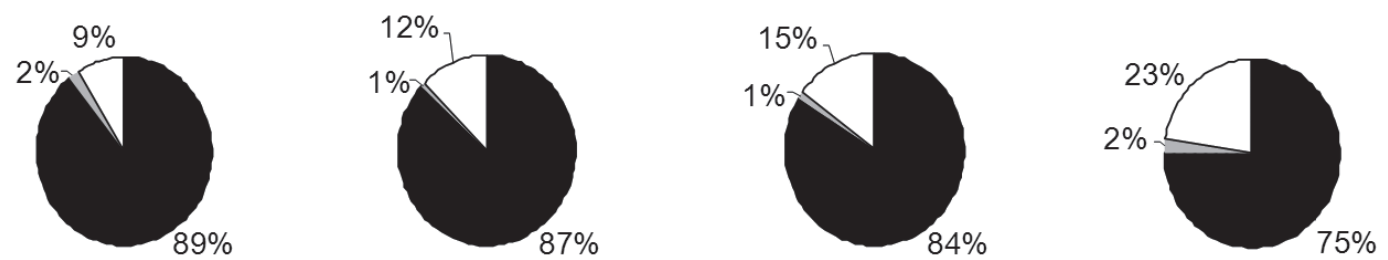

Fig. 2: Distribution of abundance (A - upper row-) and richness (B -lower row-) values for $\mathrm{C}_{3}$ plants (black), $\mathrm{C}_{4}$ plants (white) and intermediate $\mathrm{C}_{3}-\mathrm{C}_{4}$ plants (grey) at the studied sites (island in the lower delta of the Paraná River, LD; Puerto Constanza, PC; Ceibas, CE; Villaguay, VI).

Distribución de los valores de abundancia (A- fila superior) y riqueza (B- fila inferior) de las plantas $\mathrm{C}_{3}$ (negro), $\mathrm{C}_{4}$ (blanco) e intermedias $\mathrm{C}_{3}-\mathrm{C}_{4}$ (grises) en los sitios estudiados (isla del bajo delta del Río Paraná, LD; Puerto Constanza, PC; Ceibas, CE; Villaguay, VI). 
continental wetland in the Pampean Region. These results may indicate that although $\mathrm{C}_{4}$ species are included in the diet of coypus from both sites, they were consumed in different proportion. In this regard, Loponte (2008) emphasizes the importance of analyzing the isotopic composition of the diets using ranges rather than averages. This author suggests the use of larger samples to increase the variability in $\delta^{13} \mathrm{C}$ values, especially in a micropatchy environment like the Paraná wetland.

The capybaras showed a tendency to consume a greater proportion of $\mathrm{C}_{3}$ plants in $\mathrm{VI}$ than in $\mathrm{LD}$ and $\mathrm{PC}$, and a greater proportion of $\mathrm{C}_{4}$ plants at the two latter sites. In regard to plant species, Quintana et al. (1994) reported that in $\mathrm{LD}$ a single $\mathrm{C}_{3}$ plant (Carex riparia Curtis var. chilensis (Brong) Kukenth) represented between 30 and $66 \%$ of the capybara diet throughout the year. At this same site, Quintana (2002) found that the capybara consumed this plant in greater proportion than available. This preference for $C$. riparia might be concealed at the level of the functional groups, where other $\mathrm{C}_{3}$ species less consumed for the rodent are included. A different tendency was observed for the $\mathrm{C}_{4}$ plants, which were consumed in greater proportion than available in spring, despite the fact that they were less represented in the diet throughout the year. Quintana (2002) reported that the $\mathrm{C}_{4}$ plants $C$. dactylon and $P$. grumosum were consumed in greater proportion than available, thus indicating that the preference of capybara by $\mathrm{C}_{4}$ plants was also recorded at the species level. On the other hand, capybaras consumed both photosynthetic groups in greater proportion than available. The preference by Panicum hians Niess would account for the preference for $\mathrm{C}_{4}$ plants, while the $\mathrm{C}_{3}$ photosynthetic type was not related to any $\mathrm{C}_{3}$ plant species consumed by the rodent in greater proportion than available (Quintana 2002). This same result was obtained in PC for the $\mathrm{C}_{3} \mathrm{C}_{4}$ functional group.

The dietary composition of greater rheas and plains vizcachas from $\mathrm{CE}$ was dominated by $\mathrm{C}_{3}$ plants throughout the year. The comparison of abundances in the diet and in the vegetation in spring indicates that this group was consumed according to availability. The diet of these animals contained a low proportion of the $\mathrm{C}_{4}$ functional group throughout the year and it was consumed in lower proportion than available in spring. These results suggest that the patterns of forage selection may change the proportion of the photosynthetic groups in the herbivore tissues, regardless of their proportion in the environment. The patterns involve factors and mechanisms related to intrinsic properties of both the herbivores and the vegetation (e.g., species palatability) and to the availability of the latter in the environment (Boutton et al. 1980, Quintana et al. 2002, Sponheimer et al. 2003). In addition, Tykot et al. (2009) pointed out that metabolism and body mass should be also considered in dietary reconstructions.

\section{TABLE 3}

Czekanowski similarity values (\%) of photosynthetic types among sites (island in the low er delta of the Paraná River, LD; Puerto Constanza, PC; Ceibas, CE; Villaguay, VI) A) for vegetation B) for environments actually used by capybaras, EU Capybara; C) for environments actually used by cattle, EU Cattle; D) for the annual diet of capybaras, and E) for the annual diet of cattle.

Valores del coeficiente de similitud de Czekanowski

(\%) de los tipos fotosintéticos entre sitios (LD, PC, CE y VI) (isla del bajo delta del Río Paraná; Puerto

Constanza, PC; Ceibas, CE; Villaguay, VI) A) para la vegetación, B) para los ambientes de cada sitio efectivamente utilizados por el carpincho, EU Capybara; C) para los ambientes de cada sitio efectivamente utilizados por el ganado, EU Cattle; D) para la dieta anual del carpincho y E) para la dieta anual del ganado

LD PC $\quad$ VI

$\begin{array}{lllll}\text { A) Vegetation } & \text { PC } & 77.6 \% & & \\ & \text { VI } & 91.7 \% & 84.5 \% & \\ & \text { CE } & 87.9 \% & 87.6 \% & 91.4 \%\end{array}$

B) EU Capybara $\quad$ PC $\quad 88.3 \%$

VI $\quad 91.2 \% \quad 97.2 \%$

C) Eu Cattle $\quad$ VI $\quad 90.3 \%$

CE $\quad 89.1 \% \quad 81.9 \%$

D) Capybara diet $\quad \mathrm{PC} \quad 79.5 \%$

VI $\quad 73.7 \% \quad 60.7 \%$

E) Cattle diet $\quad$ VI $\quad 69.0 \%$

CE $\quad 90.1 \% \quad 68.3 \%$




\section{TABLE 4}

Sorensen similarity values (\%) of photosynthetic types consumed in the different environments (island in the lower delta of the

Paraná River, LD; Puerto Constanza, PC; Ceibas, CE; Villaguay, VI) by the coexisting species (C: capybara; CT: cattle; PV: Plains vizcacha; GR: greater rhea) over the seasons (SPR: spring, SUM: summer, AUT: autumn, WIN: winter)

Valores de similitud de Sorensen (\%) de los tipos fotosintéticos consumidos en los diferentes ambientes (isla del bajo delta del Río Paraná, LD; Puerto

Constanza, PC; Ceibas, CE; Villaguay, VI) de las especies coexistentes (C: carpincho; CT: vaca PV: vizcacha; GR: ñandú) entre estaciones (SPR: primavera, SUM: verano, AUT: otoño, WIN: invierno)

\begin{tabular}{lcccc}
\hline & \multicolumn{4}{c}{ Seasons } \\
\cline { 2 - 5 } & SPR & SUM & AUT & WIN \\
\hline PC & & & & \\
C-CT & $71 \%$ & $100 \%$ & $100 \%$ & $100 \%$ \\
VI & & & & \\
C-CT & $89 \%$ & $90 \%$ & $95 \%$ & $86 \%$ \\
CE & & & & \\
CT-RP & $98 \%$ & $87 \%$ & $85 \%$ & $90 \%$ \\
CT-GR & $85 \%$ & $93 \%$ & $96 \%$ & $95 \%$ \\
RP-PV & $71.62 \%$ & $83 \%$ & $80 \%$ & $86 \%$ \\
\hline
\end{tabular}

Loponte (unpublished data) found a value of $\delta^{13} \mathrm{Cco}-12 \%$ in an archeological specimen of capybara located in LD (Fredes stream). It is an indicator of an intake of $\mathrm{C}_{4}$ plants higher than $60 \%$. In this case, the isotopic value would result from the presence of maize crops at the studied archeological site. There are several examples of the effect of maize crops as attractors of wild animals in archeological sites (Balée 1989, Balée \& Gély 1989), as was observed with capybaras in LD (J Pita, personal communication, 2008). The relationship between agriculture and wildlife may be seen as an early adaptation of animals to environmental manipulation by humans (Tzima et al. 2007). Although there is no information on the changes introduced by man in the environment during the Late Holocene, these would probably have affected the feeding behavior of herbivores in the lower section of the Del Plata Basin (Loponte 2008).
From an ecological point of view, the foraging pattern of an herbivore may also be affected by its interaction with other coexisting herbivores. Under limited resource conditions, this interaction could lead to competition and changes in the foraging behavior of the less efficient species (Wiens 1992). In the present study, the diet of coexisting herbivores showed high similarity values in terms of functional types, as was similarly found at the plant species level (Quintana et al. 1998a, 1998b, Pereira et al. 2003). This suggests similar feeding patterns, which in turn may lead to a strong interaction under conditions of scarce forage. In a similar way to pointed out about preference patterns, inferences about competitive interactions among herbivore species taking into account only functional types are not correct because herbivores uses to select their diets according to nutritional attributes and palatability of plant species and these aspects are not directed linked with the photosynthetic types.

However, in $\mathrm{CE}$ the diet of the greater rheas differed from those of the plains vizcacha and cattle (except for winter; Pereira et al. 2003). At the level of the photosynthetic groups, the feeding patterns were concealed by the high similarity values observed when comparing the seasonal diets of greater rheas (71 \%), cattle and plains vizcachas, while similarity was low or absent at the species level. Therefore, the results obtained at the level of photosynthetic groups may include not only the relationship between a herbivore and the vegetation, but also among herbivores sharing a habitat.

On the other hand, when analyzing past dietary patterns, it should be kept in mind that the $\delta^{13} \mathrm{C}$ value from bone tissue represents an average of the diet of the last five to ten years of the animal's life (Ambrose \& DeNiro 1989, Tieszen \& Boutton 1989). Deep changes in the environmental conditions could be masked during this time period. Particularly for the Delta del Paraná River region, El Niño Southern Oscillation events and droughts have been recorded during the last 20 years (Zoffoli et al. 2008). In consequence, to reconstruct more representative past trophic chains at the site level, one needs to be very cautious in the 
analysis of temporally heterogeneous regions like the one studied here (Malvárez 1997).

This study analyzes the relationships between the current diets of different herbivores and their different habitats in terms of functional groups. The interpretation and discussion of the results is based on different concepts from the ecological theory of plantherbivore interaction. In this approach, our results allow to infer that the use of photosynthetic types may mask patterns of foraging preference, habitat selection and interactions among herbivores under limited resource conditions. These may become apparent when analyzing herbivore feeding patterns at the level of the genus or species of plants consumed. In brief, one should be cautious when inferring the relationship between the diet of herbivores and their environment in terms of photosynthetic types from current models. The environmental conditions during the quaternary based on the $\mathrm{d}^{13} \mathrm{C}$ values in fossil and subfossil animal tissues may not be directly related to the photosynthetic types consumed and those present in the environment (Tykot et al. 2009).

\section{ACKNOWLEDGEMENTS}

We want to express our gratitude to Dr. Mark Brinson, Dr. Héctor D' Antoni and Dr. Luciano Valenzuela for the revision of an earlier draft of this manuscript. This work was supported by the Agencia de Promoción Científica Tecnológica (Argentina) under grant PICT 1849 from and by the UBACyT Program of the University of Buenos Aires (Argentina) under grant X481.

\section{LITERATURE CITED}

ACOSTA A \& D LOPONTE (2002-2004) Presas y predadores: Avances en la composición isotópica de la dieta de los grupos prehispánicos del sector centro-oriental de la Región Pampeana. Arqueología 12: 105-134.

AMBROSE SH (1993) Isotopic analysis of paleodiets: Methodological and interpretative considerations: 59-130. In: Sandford MK (ed) Investigations of Ancient Human tissue: Chemical analysis in Anthropology. Gordon \& Breach Science Publishers, Amsterdam.

AMBROSE SH \& MJ DENIRO (1986) The isotopic ecology of East African mammals. Oecologia 69: 395-406.

AMBROSE SH \& MJ DENIRO (1989) Climate and habitat reconstruction using stable carbon and nitrogen isotope ratios of collagen in prehistoric herbivore teeth from Kenya. Quaternary Research 31: 407-422.

BALEE W (1989) The culture of Amazonian forests. Resource management in Amazonia: Indigenous and folk strategies. In: Posey DA \& W Balée (eds) Resource management in Amazonia: Indigenous and folk strategies. Advances in economic botany 7: 1-21. The New York Botanical Garden Bronx, New York, USA.

BALÉE W \& A GÉLY (1989) Managed forest succession in Amazonia: The Ka'apor case. In: Posey DA \& W Balée (eds) Resource management in Amazonia: Indigenous and folk strategies. Advances in economic botany 7: 129157. The New York Botanical Garden Bronx, New York, USA.

BLACK CC (1971) Ecological implications of dividing plants into groups with distinct photosynthesis production capacities. In: Cragg JB (ed) Advances in Ecological Research: 87-114. Academic Press, New York, USA.

BLACK CC, TM CHEN \& RH BROWN (1969) Biochemical basis for plant competition. Weed Science 17: 338-334.

BOTHA MS \& WD STOCK (2005) Stable isotopes composition of feaces as an indicator of seasonal diet selection in wild herbivores in southern Africa. South African Journal of Science 101: 371374.

BOUTTON TW, N BRUCE, BN SMITH \& A TYRONEHARRISON (1980) Carbon isotope ratio and crop analyses of Arphia (Orthoptera Acrididae) species in southeaster Wyoming Grassland. Oecologia 45: 299-306.

CAVAGNARO R (1988) Distribution of $\mathrm{C}_{3}$ and $\mathrm{C}_{4}$ grasses at different altitudes in a temperate arid region of Argentina. Oecologia 76: 273-277.

CERLING TE, JM HARRIS, BJ MACFADDEN, MG LEACEY, J QUADE, V EISENMANN \& JR EHLERINGER (1997) Global variations during through the Miocene/Pliocene boundary. Nature 389: 153-158.

DENIRO MJ (1987) Stable isotopes and archeology. American Scientist 75: 182-191.

DENIRO MJ \& S EPSTEIN (1978) Influence of diet on distribution of carbon isotopes in animals. Geochimica et Cosmochimica Acta 42: 495-496.

EHLERINGER JR \& RK MONSON (1993) Evolutionary and ecological aspects of photosynthetic pathway variation. Annual Review of Ecological Systems 24: 411-439.

FARQUHAR GD, JR EHLERINGER \& L HUBICK (1989) Carbon isotope discrimination and photosynthesis. Annual Review of Plant Physiology and Plant Molecular Biology 40: 503537.

FERANEC RS (2003) Stable isotopes, hypsondonty, and the palodiet of Hemiauchenia (Mammalia: Camelidae): A morphological specialization creating ecological generalization. Paleobiology 29: $230-242$.

FERNÁNDEZ J, HO PANARELLO \& J SCHOBINGER (1999) The Inka mummy from Mount Aconcagua: Decoding the geografic origen of the "Messenger to the Deities" by means of stable carbon, nitrogen, and sulfur isotope analysis. Geoarchaeology 14: 27-46.

HOBBS NT (1982) Confidence intervals on food preference indices. Journal of Wildlife Managment 46: 505-507. 
HOOPE KA, R AMUNDSON, M VAVRA, MP MACCLARAN \& DI ANDERSON (2004) Isotopic analysis of tooth enamel carbonate from modern North American feral horses: Implications for paleoenvironmental reconstructions. Palaeogeography, Palaeoecology 203: 299-311.

JONES MB (1988) Photosynthetic responses of $\mathrm{C}_{3}$ and $\mathrm{C}_{4}$ wetlands species in a tropical swamp. Journal of Ecology 76: 253-262.

KANDUS P, AI MALVÁREZ \& N MADANES (2003) Estudio de las comunidades de plantas naturales de las islas del bajo delta del Río Paraná. (Argentina). Darwiniana 41: 1-16.

KOCH PL, ML FOGEL \& N TUROSS (1995) Tracing the diet of fossil using stable isotopes. In: Lajtha K \& RH Michener (eds) Stable isotopes. Ecology and Environmental Science: 63-92. Blackwell Scientific Publications, Oxford, England.

LOPONTE D (2008) Arqueología del humedal del Paraná Inferior (bajíos ribereños meridionales). In: Acosta A \& D Loponte (eds) Serie arqueología de la cuenca del Plata. Instituto Nacional de Antropología y Pensamiento Latinoamericano, Buenos Aires, Argentina.

MALVÁREZ AI (1997) Las comunidades vegetales del delta del Río Paraná. Su relación con factores ambientales. PhD. Thesis. Facultad de Ciencias, Universidad de Buenos Aires, Buenos Aires, Argentina.

MANLY BF, L MCDONALD \& DL THOMAS (1993) Resource selection by animals: Statistical design and analysis for field studies. Chapman \& Hall, London.

MATTEUCCI S \& A COLMA (1982) Metodología para el estudio de la vegetación. Secretaría Gral. de la OEA. Programa Regional de Desarrollo Científico y Tecnológico 22, Washington, USA

PEREIRA J, RD QUINTANA \& S MONGE (2003) Diets of plains vizcacha, greater rhea and cattle in Argentina. Journal of Range Management 56: 1320.

QUINTANA RD (2002) Influence of livestock grazing on the capybara's trophic niche and forage preferences. Acta Therologica 47: 175-183.

QUINTANA RD (2003) Seasonal effects on overlap trophic niche between capybara (Hydrochaeris hydrochaeris) and livestock and on trophic niche breadths in a rangeland of Central Entre Ríos, Argentina. Mammalian 67: 33-40.

QUINTANA RD, S MONGE \& AI MALVÁREZ (1994) Feeding habits of capybara (Hydrochaeris hydrochaeris) in forestation areas of the lower delta of the Paraná River, Argentina. Mammalian 58: 569-580.

QUINTANA RD, S MONGE \& AI MALVÁREZ (1998a) Composición y diversidad de las dietas de capibara (Hydrochaeris hydrochaeris) y del ganado doméstico en un agroecosistema del centro de Entre Ríos, Argentina. Ecotrópicos 11: 34-44.

QUINTANA RD, S MONGE \& AI MALVÁREZ (1998b) Feeding patterns of capybara Hydrochaeris hydrochaeris (Rodentia, Hydrochaeridae) and cattle in the non-insular area of the Lower Delta of the Paraná River, Argentina. Mammalian 62: 37-52.

QUINTANA RD, R BÓ \& F KALESNIK (2002) La vegetación y la fauna silvestres de la porción terminal de la cuenca del Plata. Consideraciones biogeográficas y ecológicas. In: Bortharagay JM (ed) El Río de la Plata como territorio: 99-124. Facultad de Arquitectura y Urbanismo, Universidad de Buenos Aires y Ediciones Infinito, Buenos Aires, Argentina.

QUINTANA RD, N MADANES, AI MALVÁREZ, FA KALESNIK \& M CAGNONI (2005) Caracterización de la vegetación en tres tipos de hábitat de carpinchos en la baja cuenca del Río Paraná, Argentina. Temas de la Biodiversidad del Litoral fluvial argentino II INSUGEO. Miscelánea 14: 83-96.

SAGE RF, DA WEDDIN \& M LI (1999) The biogeography of $\mathrm{C}_{4}$ photosynthesis patterns and controlling factors. In: Sage RF \& RK Monson (eds) $\mathrm{C}_{4}$ plant biology: 313-373. Academic Press, San Diego, USA.

SCHWARCZ HP (1991) Some theoretical aspects of isotope paleodiet studies. Journal of Archaeological Science 18: 261-275.

SMITH BN \& WV BROWN (1973) The Kranz syndrome in the Gramineae as indicated by carbon isotopic ratios. American Journal of Botany 60: 505-513.

SPONHEIMER M, T ROBINSON, B ROEDER, J HAMMER, L AYLIFFE, B PASSEY, D CERLING \& JR EHLERING (2003) Digestion and passage rates of grass hays by llamas, alpacas, goats, rabbits, and horse. Small Rumiant Research 48 . 149-154.

THEERL JA \& LG STOWE (1976) Climatic patterns and the distribution of $\mathrm{C}_{4}$ grasses in North America. Oecologia 23: 1-12.

TIESZEN LL (1991) Natural variations in the carbon isotope values of plants: Implications for arqueology and paleoecology. Journal of Archaeological Science 18: 227-248.

TIESZEN LL \& TW BOUTTON (1989) Stable carbon isotopes in terrestrial ecological research. In Rundel PW, JR Ehleringer \& KA Nagy (eds) Stable isotopes in ecological research: 167-195. Ecological Studies 68, Springer-Verlag Press, Berlin, Germany.

TYKOT RH, F FALABELLA, MT PLANELLA, E ASPILLAGA, L SANHEUZA \& C BECKER (2009) Stable isotopes and archaeology in Central Chile: Methodologogical insights and interpretative problems for dietary reconstruction. International Journal of Osteoarchaeologu 19: 156-170.

TZIMA FA, AL SYMEONIDI \& PA MITKAS (2007) Symbiosis: Using predator-prey games as a test bed for studying competitive co-evolution. International conference on integration of Knowledge Intensive Multi-Agent Systems (KIMAS): 115-120.

VAN DER MERWE NJ (1989) Natural variation in ${ }^{13} \mathrm{C}$ concentration and its effect on environmental reconstruction using ${ }^{13} \mathrm{C} /{ }^{12} \mathrm{C}$ ratios in animal bones. In: Price TH (ed) The Chemistry of Prehistoric Human Bone: 105-125. Cambridge University Press, Cambridge, England.

WALLER SS \& JK LEWIS (1979) Occurrence of $\mathrm{C}_{3}$ and $\mathrm{C}_{4}$ photosynthetic pathways in North American grasses. Journal of Range Management 32: 1228.

WIENS JA (1992) Ecology of bird communities. First edition. Cambridge University Press, Cambridge.

YACOBACCIO HD, MR MORALES \& T SAMEC (2009) 
Towards an isotopic ecology of herbivory in the Puna ecosystem: New results and patterns on Lama glama. International Journal of Osteoarchaeology 19: 144-155

ZOFFOLI ML, P KANDUS, N MADANES \& DH

Associate Editor: Julio R. Gutiérrez

Received July 29, 2009; accepted April 1, 2010
CALVO (2008) Contribution of NOAA-AVHRR NDVI time series to seasonal and interannual analysis of wetlands in South America: The case of the Paraná Delta Region (Argentina). Landscape Ecology 23: 833-848. 
